\title{
Interactive comment on "Microphysical
} investigation of the seeder and feeder region of an Alpine mixed-phase cloud" by Fabiola Ramelli et al.

\section{Anonymous Referee \#1}

Received and published: 18 October 2020

Review: Microphysical investigation of the seeder and feeder region of an Alpine mixedphase cloud Ramelli et al. Atmospheric Chemistry and Physics

This is a very well written paper. It is properly referenced, and logically presented. The data are novel and interpreted carefully. The Conclusions are reasonable. The figures are clear and easy to follow. I recommend publication.

Major comments:

None

Minor comments: 
My only real concern with the paper is the speculative nature of the interpretation of processes within the generating cells. Without in-situ measurements, the interpretations are necessarily speculative, but I think the authors have been careful to keep their speculations constrained by the dataq available to them. For that reason, I don't believe any changes are necessary.

Interactive comment on Atmos. Chem. Phys. Discuss., https://doi.org/10.5194/acp-2020-772, 2020. 